\title{
Súčasné bioetické problémy determinujúce život krestanskej rodiny
}

\author{
Current bioethical problems determining the life \\ of a christian family
}

\begin{abstract}
The present contribution provides an insight into selected bioethical issues that have a direct impact on the life of a contemporary Christian family. It examines different approaches with which one encounters when searching for the right way out of the problem of a married couple's infertility. The resolution of this problem can be found in an artificial insemination, which offers contemporary modern medicine, as well
\end{abstract}

as adoption, which, as an obvious act of love, also takes into consideration the benefits and overal utility for orphans or abandoned children. The main aim is to outline such a potential solution that would be based both on theological teachings of the Orthodox Church and its spiritual experience.

Keywords: family, marriage, childlessness, artificial insemination, adoption

V súčasnosti je rodina viac ako kedykolvek v minulosti vystavená mnohým rizikám a nebezpečenstvám, ktoré ohrozujú jej zdravý, prirodzený a krestanský duchovný život. Jednou z oblastí, ktorá nielen ovplyvňuje, ale často vymedzuje alebo priamo ohrozuje život dnešnej rodiny je aj bioetika.

Vel'mi stručne povedané, bioetika predstavuje vedu s rozsiahlym súhrnom vedeckých poznatkov, ktoré sú výsledkom prudkého rozvoja biológie a medicíny v druhej polovici 20 . storočia ${ }^{1}$. Aj začiatok 3. tisícročia sa nesie v duchu

1 M. Župina, Význam terminológie v bioetike, „Pravoslávny Teologický Zborník“ XXXIX (24) 2013, s. 60. 
nevídaného rozšírenia teritória bioetiky hlavne o otázky aplikovania modernej medicínskej technológie a to v celej šírke ludského života od počatia až po smrt'. Potvrdzuje to aj grécky teológ M. Vantsos, ked' hovorí, že „súčasná bioetika skúma určité eticky problematické aplikovanie medicíny a biológie predovšetkým vo vztahu k začiatku a koncu života človeka"2.

Bioetika zvlášt skúma etické problémy, ktoré sú spojené:

- s neplodnostou, asistovanou reprodukciou, predpôrodným vyšetrením, potratom (interrupciou) a príslušnými témami v kontexte začiatku života človeka;

- so zásahmi pre zachovanie alebo zdokonalenie ludského života, klonovaním, transplantáciou tkanív alebo orgánov;

- s otázkou smrti, poslednou fázou ludského života - starobou, paliatívnou starostlivostou, eutanáziou a súvisiacimi otázkami.

Sme si vedomí, že oblast' bioetiky je dnes nesmierne široká a dynamická, a $\mathrm{z}$ tohto dôvodu sme sa zamerali len na niektoré vybrané otázky, ktorými chceme poukázat' na skutočnost', do akej miery moderné biotechnologické výsledky súčasnej medicíny determinujú život dnešnej krestanskej rodiny.

Začneme tam, kde sa začína samotný ludský život a kde sa súčasne, žial', aj niekedy končí manželské spolužitie nemalého počtu neplodných párov. Pokial' im nie je Bohom požehnané splodit dieta prirodzeným spôsobom, v mnohých prípadoch „zaklope na dvere“ bioetika so svojimi alternatívami. Ako zaujat správny postoj v spleti rôznych ponúk a možností, ktoré dnes ponúka moderná medicína? Ktoré sú rozhodujúce kritériá, aby sa dnešný človek vedel rozhodnút v súlade s krestanskou vierou, etikou a duchovným životom? Aký je v tejto nelahkej problematike postoj Pravoslávnej cirkvi?

\section{Otázka umelého oplodnenia}

Umelé oplodnenie sa akosi stalo hned' prvou alternatívou v prípade riešenia otázky neplodnosti jedného z manželov. Jeho odbornejší ekvivalent znie asistovaná reprodukcia. Súčasné reprodukčné techniky môžu na jednej strane naplnit očakávania neplodných párov, uspokojit ich hlbokú potrebu rodičovstva a tiež prispiet’ k zintenzívneniu manželskej jednoty a vytvoreniu rodinnej harmónie, na druhej strane môžu generovat' bezprecedentné problémy etického, lekárskeho, psychologického, právneho a sociálneho charakteru. Tieto prob-

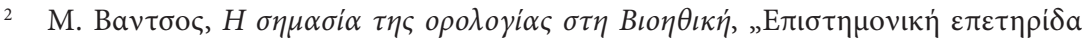

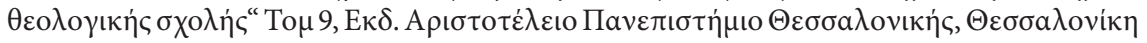
2004, б. 147. 
lémy sú totiž výsledkom využitia modernej technológie v tom najosobnejšom a hlboko duchovnom, posvätnom akte. Ich rozsah, rôznorodost’ a závažnost' závisia od aplikovaných metód i podmienok, za ktorých sú implementované a, samozrejme, aj od mnohých d’alších sprievodných faktorov.

Umelé oplodnenie je bezpochyby pôsobivým lekárskym a biologickým výsledkom s významnými spoločenskými dopadmi. Je spojené so zrodením novej ludskej bytosti, teda s udalostou, ktorá je vítaná so zvláštnym obdivom, úctou a radostou. Zároveň však nie je správne ignorovat otázku kvality života novej bytosti a jej rodičov. Pre Pravoslávnu cirkev znamená kvalita ludského života nielen biologickú a psychologickú integráciu a sociálne zabezpečenie, ale tiež možnost' duchovného rozvoja, zdokonalovania sa. Tento duchovný rozmer dodáva človeku zmysel psychosomatickej harmónie a možnost’ existenciálneho naplnenia, ontologického zmyslu a ciela.

Základným prvkom pravoslávnej krestanskej antropológie je identifikácia posvätnosti ludskej existencie, ktorá súvisí s existenciou hmotného a nehmotného sveta. Cielom života človeka, ktorý je stvorený na Boží obraz, je nadobudnút stav „podla jeho podoby ${ }^{\text {c3 }_{3}}$, teda dosiahnut posvätenie, zbožštenie ${ }^{4}$. S týmto najvyšším cielom človek pracuje, zakladá rodinu, kultivuje umenie a vedu, organizuje spoločnost'. Z tohto dôvodu, ak niekto manipuluje s človekom, alebo s ním dokonca experimentuje, vstupuje do posvätného aktu a mal by tak konat' s bázňou a rešpektom pred Bohom. Navyše človek nie je príčinou svojej vlastnej existencie. Každá zmienka o počiatku života by preto mala byt učinená s úctou, a nie s aroganciou. Bud' hladíme na Boha ako na toho, kto dáva život a približujeme sa k Nemu s bázňou, alebo Boha ignorujeme a konáme tak, ako by sme boli „bohmi“. Avšak, nezabúdajme, cena takejto arogancie je vysoká.

Samozrejme, ludská túžba po detoch je prirodzená, a dá sa povedat aj posvätná. Cirkev v nej rozpoznáva plán Boha - Stvoritela, ktorý stvoril človeka, aby participoval na jeho blaženosti. Anatómia, fyziológia, menštruačný cyklus, hormonálna rovnováha a celková psychológia ženského pohlavia sú orientované na materstvo. Počas tehotenstva žena ako potenciálna matka až do najkrajnejšej miery dokáže vyzdvihnút charakteristiku svojho pohlavia a prirodzenosti. Základná funkcia ženského tela, na ktorú je zameraná celá existencia ženy, je reprodukčná. Žena existuje anatomicky, fyziologicky a citovo pre plod, tehotenstvo a pôrod - zrod nového života. Ekvivalentom potreby materstva je taktiež potreba otcovstva. $Z$ tohto dôvodu Cirkev uznáva, že neplodnost’ a následná bezdetnost’ sa môžu stat' tažkým krížom, ktorý často vedie k intenzívnej

$1 \mathrm{Mjž} 1,26$.

4 M. Župina, Svätootcovská skúsenost ako ukazovatel pravoslávnej teológie, Vyd. Prešovská univerzita v Prešove, Pravoslávna bohoslovecká fakulta, Prešov 2013, s. 98-100. 
psychickej úzkosti a niekedy aj k tažko riešitelným problémom, ktoré narušujú harmonické súžitie manželov. Cirkev navyše vidí v každej ludskej bytosti spolu s jej prirodzenou identitou (biologickou, psychologickou, atd.) aj jej nekonečné duchovné možnosti. Tým pádom sa jednoznačne stavia proti názoru, že neplodnost predstavuje typ „trestu“, postihnutia či sociálnej slabosti. Často krát, naopak, manželské páry, ktoré majú problém s počatím dietata, majú správnu duchovnú orientáciu a sú obzvlášt aktívne v rôznych oblastiach spoločenského a duchovného života 5 .

Sledujúc súčasný vedecký a technologický vývoj si Cirkev uvedomuje, že ludské túžby, ktoré kedysi boli iba v rovine snov, sa teraz naplñajú. Víta takúto nádej s pochopením, ale zároveň vníma, že technologický vývoj často transformuje túžby do potrieb a stažuje tak zápas o duchovnú slobodu. Snahou Cirkvi by malo byt zásadným spôsobom eliminovat’ nezdravé názory a neoprávnené spoločenské tlaky. Spolu s tým by sa mal predostierat postoj, že zatial' čo narodenie dietata je vel'kým požehnaním, neplodnost’ neznamená automaticky „trest“ či stratu požehnania, takýto manželský pár nie je degradovaný, nijako sa „nepoškodzuje“ vztah obidvoch manželov a už vôbec sa neruší ich manželstvo.

Trvalá snaha prekonat’ neplodnost’ skrýva v sebe riziko premeny prirodzenej a posvätnej túžby po detoch do tvrdošijnej vôle, ktorá sa stavia proti Božej vôli. Každý pokus o liečbu neplodnosti by mal ponechat priestor pre pokorné prijatie aj možného neúspechu. Aj ked’ počiatok každej ludskej bytosti pochádza z ludskej vôle, je zároveň vôlou Boha. Súčasná technológia je velkým požehnaním, ktoré dáva Boh človeku, pokial’ je použitá s rešpektom a hlavne s pokorou. Zároveň však môže človeka postavit’ do opozície voči Božej vôli, ktorá sa prejavuje prírodnými či biologickými zákonmi, a v takom prípade môže človek - nakolko je slobodnou bytostou - trvat na svojej vlastnej vôli, ktorá je nekompatibilná s Božou vôlou, a dožadovat’ sa umelého oplodnenia.

Je však potrebné vediet', že zmyslom každej novej ludskej osoby nie je ozdobif život rodičov či rozmnožit ich bohatstvo. Nový človek patrí Bohu a je určený pre večný život. Je darom, ktorý Boh dáva rodičom pre tento pozemský život. Človek sa rodí predovšetkým preto, aby vyjadril Božiu kenotickú lásku, a až sekundárne preto, aby svojím životom uspokojil citové a spoločenské potreby rodičov. Z týchto dôvodov by malo byt počatie každej ludskej bytosti výrazom Božej vôle a nie výsledkom čisto ludského rozhodnutia. Inými slovami, každý človek by mal byt plodom pokornej a slobodnej zhody rodičovskej vôle s vôlou Boha. Najväčším Božím darom človeku je slobodná vôla, najnebezpečnejšou hrozbou pre človeka je jeho vlastná ludská vôla.

5 Nikolaos, metr., The Greek Orthodox position on the ethics of assisted reproduction, „Ethics, Bioscience and Life“ Vol. 3, No. 3 (2008), p. 26. 


\section{Posvätnosfi počiatku l'udského života}

Spôsob, akým vzniká ludský život, je posvätný; táto udalost’ sa odohráva tajomne. Odráža to najintenzívnejšie vyjadrenie lásky medzi manželmi. Moderné technológie nás dnes uvádzajú do logiky sexuálneho styku bez reprodukcie a do logiky reprodukcie bez sexuálneho styku. Dynamika vysoko vyspelej technológie vyvádza počiatok života $\mathrm{z}$ tepla a tajomstva hmotného tela do chladu a priehlladnosti skúmavky. Opúšta jedinečnost' partnerovej prítomnosti, ktorú nahrádza prítomnostou lekárskeho personálu. Počas posvätného okamihu vzniku života nie sú rodičia spolu, dokonca nie sú ani prítomní. Dieta je „vyrobenéc lekármi a zdravotným personálom, nie je počaté svojimi rodičmi. Navyše často nemusí byt pre reprodukciu použitý genetický materiál rodičov, ale cudzieho darcu (!).

Biologický počiatok je vymedzený okamihom splodenia človeka ako psychosomatickej bytosti s vrodeným potenciálom „stat'sa Božím dietatom“. Splodenie znamená začiatok existencie človeka, začiatok „zázraku“ života. Tento začiatok ludského biologického života je stotožnený s jedinečnou udalostou zásadného významu - zrodením novej duše. Teda už v embryu sa okrem telesného rastu a prenosu zdedených charakteristík, ktoré formujú osobnost', uskutočňuje d’alší proces, zrodenie a rozvoj duše $e^{7}$. O simultánnom zrodení duše a tela svedčí napríklad svätý Gregor Nysský, ktorý hovorí: „Pretože človek je jedna bytost' pozostávajúca $\mathrm{z}$ duše a tela, musíme predpokladat', že počiatok jeho existencie je jeden a spoločný pre obidve zložky, aby človek nemohol byt’ voči sebe samému starší a mladší zároveň, keby jeho telesná zložka bola staršia a tá duševná, naopak, mladšia (...) Čo sa týka samotného stvorenia človeka, nesmieme klást̉ jeho jednu čast’ pred druhú, t. j. ani dušu pred telo, ani telo pred dušu“8. Spolu so svojou dušou bude embryo prechádzat z podmienok ludského „odetia“ do stavu božského „šatu“, z času do večnosti, z úpadku do neporušenosti, z fyzickej podobnosti rodičov do duchovnej podobnosti Bohu. V ludskom embryu už pokorne existuje Boží obraz. Tak ako rozvoj ludského tela vyžaduje devätmesačnú biologickú prípravu - tehotenstvo - aj proces prejavenia sa duše v človeku potrebuje určitý čas od počatia po jeho zavŕšenie. Čím úplnejší je proces ludského biologického vývinu, tým väčšia je miera prítomnosti duševných funkcií. Počas toho, ako telo rastie a zdoko-

6 Jn $1,12$.

7 M. Šipová, Asistovaná reprodukcia v kontexte l’udského práva na život, „Pravoslávny Biblický Zborník“ zv. III(2014), s. 136.

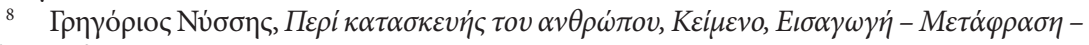

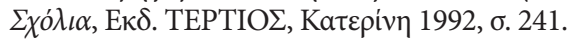


naluje sa, hovorí svätý Gregor Teológ, postupne sa rozvíja aj múdrost', skúsenost' i cnost' duše $e^{9}$.

Zároveň platí, že každá ludská bytost', ktorá je počatá, má svoj začiatok, avšak nemá koniec. Pre Pravoslávnu cirkev je počatie každej ludskej bytosti udalostou jedinečného významu. Božský ciel’a perspektíva večného Královstva dodáva okamihu počatia jedinečnost' a neopakovatelnost', ktorá presahuje hranice biologickej identity a pominutelného života. Stretnutie Presvätej Bohorodičky s Alžbetou a reakcia plodu svätého Jána Krstitela v jej tele po tom, čo poznal Isusa, poukazujú nielen na biologickú „mobilitu“ plodu, ale tiež na duchovný prejav ludskej duše v ňom ${ }^{10}$. Apoštol Pavol navyše v liste Galatanom tvrdí, že jeho povolanie pochádza už z obdobia tehotenstva: „Ale ked’ sa Bohu, ktorý ma od života matky vybral a svojou milostou povolal..."11. Boh teda povoláva, posväcuje, ustanovuje a menuje svojich prorokov a apoštolov už v ich embryonálnom stave.

\section{Moderné technológie}

Moderné technológie bezpochyby prispeli k výskumu v zdravotníctve a platí to aj v oblasti reprodukcie. Možno to považovat za výnimočné Božie požehnanie. Využitie technológií v spolupráci s l’udskou intervenciou, ktorá chráni a napomáha posvätnosti oplodnenia, je nielen prijatelné, ale aj žiaduce a milé Bohu. Avšak technologický rozvoj môže byt aj deštruktívny, ak vnucuje neprirodzené možnosti, ktoré majú negatívny dopad na jednotu rodiny, narúšajú súčinnost’ duchovných a prírodných zákonov a v konečnom dôsledku nahrádzajú Boha. Cirkev - akoby sa to mohlo mylne zdat - sa neobáva zmien, nie je ani proti novým objavom či pokroku. Avšak jednoznačne odmieta neúctu k stvorenstvu a človeku, a je zásadne proti znesväteniu rodiny. Oplodnenie totiž predstavuje „posvätný oltár života“, vstúpit do neho si preto vyžaduje úctu a Božiu bázeň ${ }^{12}$.

\section{Duchovná perspektíva Cirkvi}

Cirkev zahŕňa bolest', chorobu i „nedokonalost“ či postihnutie do kontextu ludského pádu. Zároveň však rešpektuje lekársku vedu. Žehná každému etic-

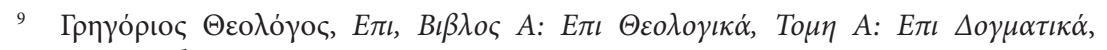
J.-P. Migne, Patrologia Graeca 37, Paris 1862, s. 453-454.

$10 \quad$ Lk 1, 44.

$11 \quad$ Gal 1, 15.

12 Nikolaos, metr., The Greek Orthodox position on the ethics of assisted reproduction, „Ethics, Bioscience and Life“ Vol. 3, No. 3 (2008), p. 30. 
ky prijatelnému lekárskemu pokusu obnovit zdravie človeka a zveruje konečné riešenie každého prípadu do Božej lásky ku každému človeku zvlášṫ. Zhrnutie cirkevného postoja môžeme nájst' v biblickej knihe Múdrosti Isusa, syna Sirachovho: „Synu, svoju chorobu nepodceňuj, ale pros Hospodina, a On ta uzdraví ${ }^{\text {"13 }}$. Cirkev čelí všetkému s trpezlivostou, pokorou a vierou. Neoddeluje životné skúšky od Božej lásky, ale vidí v nich príležitost’ pre spásu a posvätenie. Vyhýba sa špecifickým pravidlám či exkomunikácii v bioetických otázkach, vrátane umelého oplodnenia. V zásade necháva tieto otázky otvorené, aj ked’ zároveň ukazuje smer a étos $\mathrm{v}$ prístupe ku každému špecifickému prípadu. Dá sa povedat', predkladá všeobecnú „líniu“ Božej vôle, ale každému ponúka možnost' rozpoznat ju vo svojom živote.

Cirkev vzhliada na zrodenie každej ludskej bytosti v kontexte tajomstva manželstva. V dôsledku toho sa domnieva, že počiatok ludského života by mal nastat’ v atmosfére monogamného heterosexuálneho styku požehnaného svätou

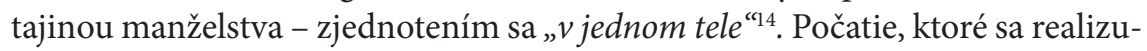
je namiesto tela matky v laboratóriu a v inom procese, ako je manželský styk, je jednoznačne ochudobnené o charakter tajomstva a posvätnosti ${ }^{15}$. Posvätenie človeka nie je uskutočňované iba rodením detí. Cirkev žehná narodeniu, ale zároveň uznáva celistvost’ a „funkčnost“" bezdetných manželstiev. Biologická neplodnost'sa môže stat' podnetom k bohatej duchovnej plodnosti manželov, pokial' pokorne príjmu do svojho života Božiu vôlu. Ak však túžba po detoch prerastie do presadzovania tvrdošijnej vôle, znamená to, naopak, duchovnú nezrelost'.

\section{Umelé oplodnenie verzus adopcia}

Problém neplodnosti niektorých manželských párov by mohol byt vyriešený adopciou. Cirkev by mala podporovat zlepšenie, propagáciu a zjednodušenie adopcie. Týmto spôsobom je možné utíšit bolesti mnohých neplodných párov, obmedzit nebezpečenstvo neúspešného tehotenstva a premôct' ludskú vôlu láskou. Cirkev nemôže odporučit umelé oplodnenie ako riešenie problému neplodnosti, avšak jej povinnostou je čelit na základe duchovného posúdenia konkrétnej realite, ktorá vznikla bez ohl’adu na jej vôlu či prianie. Pokial'budú k nej nasmerované otázky, mala by ponúknut étos svojho učenia zrozumitel'ne a slobodne.

$13 \operatorname{Sir} 38,9$.

14 Ef 5, 31.

15 M. Šipová, Asistovaná reprodukcia v kontexte ludského práva na život, „Pravoslávny Biblický Zborník“ zv. III (2014), s. 137. 
Adopcia ${ }^{16}$ ako eventualita riešenia problémov neplodnosti a bezdetnosti, ktorým čelia mnohé manželské páry, je podla Cirkvi správnejšou alternatívou a „dokonalejšou“ terapiou bezdetnosti. Adopcia je nielen riešením problému neplodnosti manželských párov, ale je aj velkým skutkom lásky, ktorý hladí aj na prospech a úžitok pre osirelé a opustené deti.

Zo štatistík (slovenských i európskych) vyplýva, že počet adopcií postupne klesá. Je zaujímavé, že okrem iných možných dôvodov sa za hlavnú príčinu znižovania počtu adopcií udáva malý počet detí, ktoré sú vlastnými rodičmi odvrhnuté a v podstate „určené “ na adopciu. Avšak je tu ešte iný závažný dôvod, ktorý zásadným spôsobom môže ovplyvňovat’ uvažovanie bezdetných rodičov o eventuálnej možnosti adoptovat’ si „cudzie“ dieta. Tým dôvodom je práve zvýšená pozornost’ väčšiny takýchto manželských párov, ktorá je nasmerovaná k neustále novým metódam asistovanej reprodukcie. Tá v istom zmysle prináša novú nádej a pre niektorých neplodných rodičov je často aj riešením ich problému, avšak, ako hovorí G. Mantzaridis, pri umelom oplodnení „z krest’anského hladiska neexistujú len určité etické podmienky, ale aj antropologické, duchovné alebo čisto teologické obavy a výhrady “17. Je čoraz zretelnejšie, že aplikovaním metód asistovanej reprodukcie sa vytvárajú nové problémy a na povrch sa dostávajú aj nové otázky, ktoré sú často ovela komplikovanejšie, ako bol „pôvodný“ problém neplodnosti manželov.

Grécky teológ V. Fanaras uvádza vel’mi zaujímavú myšlienku, ktorá nie je d’aleko od pravdy, ked' na základe svojich skúseností a poznania právneho rámca celej problematiky hovorí, že legislatívna úprava vo veci adopcie má značný pediacentrický charakter (v centre pozornosti sa nachádza dieta) a každý právny článok v prvom rade sleduje záujem dietata, jeho prospech a úžitok, zatial' čo pri obdobných legislatívnych úpravách v oblasti asistovanej reprodukcie jednoznačne prevládajú silné túžby manželov alebo aspoň jedného z nich, kde je možné oplodnenie ženy (slobodnej či vdovy) s cielom narodenia dietała - polosiroty, čo je prejavom zretel’ného egocentrizmu takejto potenciálnej matky ${ }^{18}$.

16 Pojem adopcia (adoptovanie) alebo osvojenie sú synonymá a vychádzajú z platnej právnej legislatívy: „Adopcia a osvojenie sú dva výrazy pre ten istý právny vztah. Pri adopcii prijímajú manželia alebo jednotlivec opustené diet’a a nadobúdajú k nemu rovnaké práva a povinnosti, akoby boli jeho biologickými rodičmi. Vzt’ah, ktorý medzi adoptívnymi rodičmi a dietałom vzniká, má z právneho hladiska rovnakú silu ako vztah medzi biologickými rodičmi a vlastným dietatom - je to príbuzenský vztah. To isté platí pre vztah medzi osvojencom a príbuznými osvojitela“', Adopcia (osvojenie), Ústredný portál verejnej správy Slovenskej republiky, http://portal.gov.sk/Portal/sk/Default.aspx?CatID=39\&aid=751 (21.05.2015).

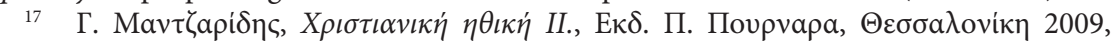
б. 580 .

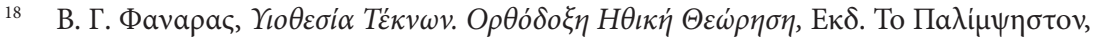
$\Theta \varepsilon \sigma \sigma \alpha \lambda$ ovíkך 2005, б. 58. 


\section{Adopcia - áno alebo nie?}

V otázke rozhodovania sa áno alebo nie adopcii dietata - nie je vylúčené, že aj po nej - sa u rodičov môžu objavovat isté pochybnosti, ktoré vznikajú v dôsledku vnútorného zápasu medzi ich vlastným egocentrizmom a vnútorným hlasom volajúcim po potrebe prejavenia lásky. To všetko sú nelahké a zložité otázky, ktoré je potrebné riešit zo správneho duchovného hladiska za pomoci skúsenosti a daru tých, ktorí sú nositelmi autentického empirického a charizmatického spôsobu duchovného života v Christu. Avšak aj zo všeobecného krestanského uhla pohladu existuje určitá eticko-duchovná stupnica podnetov či impulzov, ktorá odráža snahu o obetovanie sa v prospech a úžitok dietata a „tlmí" egocentrické pohnútky manželov.

To najdôležitejšie a najpodstatnejšie, a nielen v tejto otázke, je snaha o hladanie Božej vôle, teda toho, ako sa máme správne rozhodnút', aby to bolo v súlade s Božou vôlou. Sme si vedomí tažkosti úplného a vyčerpávajúceho zodpovedania danej otázky, avšak, aby sme sa nepohybovali len po povrchu problému, ale hladajúcim bezdetným rodičom poskytli isté duchovné východiská, uvedieme názor už vyššie uvedeného teológa V. Fanarasa, ktorý hovorí, že ak manželský pár je bezdetný, pri rozhodovaní sa ako d’alej by sa eventuálne mohol nechat oslovit uvedenou stupnicou od „najideálnejšieho“ riešenia:

a) adopcia jedného alebo aj viacerých detí,

b) prijatie neplodnosti a bezdetnosti v rámcoch Božej vôle a prenesenie rodičovskej energie a lásky, ktoré sú tak nevyužité, do rôznych foriem filantropickej služby blížnemu,

c) skúmanie možností, ktoré prináša súčasná moderná medicínska veda, a tie bud' vylúčia eventualitu mat vlastné diet̉a, alebo prinesú nádej pri klasickej liečbe neplodnosti ${ }^{19}$. Následne sa odporúča opätovné preskúmanie bodov a) alebo, b) a uvážlivé, zodpovedné rozhodnutie.

Samozrejme, hladanie Božej vôle si vyžaduje intenzívny duchovný a asketický spôsob života. Existencia narodených detí, ktoré sa bud' stali sirota$\mathrm{mi}$, alebo ich rodičia opustili a potrebujú rodičov i teplo domova v žičlivom rodinnom prostredí, nás jednoznačne privádza k záveru, že tým najsprávnejším riešením problému neplodnosti a následnej bezdetnosti je adopcia dietata.

Adopcia detí ako legislatívny akt umelého konštituovania rodiny, ktorá je založená na zákonnom práve a úprave príslušných právnych noriem rodinného práva, predstavuje prijatý spôsob a model spoločenskej praxe. Požehnanie tomuto právnemu aktu, ktoré v tradícii Pravoslávnej cirkvi sa

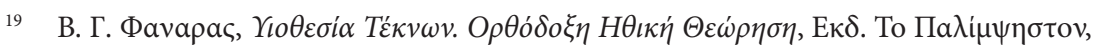

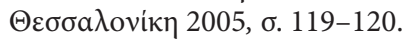


dopÍňa, správnejšie, naplňa sa konkrétnou bohoslužbou a modlitbami, dvíha adopciu zo spoločensko-právnej roviny do eticko-duchovnej a ontologickej roviny, čo so sebou prináša aj konzekvencie v soteriologickej rovine vrátane eschatologickej perspektívy, ktoré sa dotýkajú tak dietata, ako aj samotných rodičov.

V tejto otázke sme toho názoru, a vo svojej podstate aj záveru, že adopcia „nie je hladanie dietata rodine, ale hladanie rodiny dietatu“ ${ }^{\prime 20}$.

\section{Záver}

Použitie nových biomedicínskych metód môže v mnohých prípadoch liečit neplodnost'. Rozširujúce sa zasahovanie do procesu vzniku ludského života zároveň však znamená hrozbu pre duchovnú integritu i psychosomatické zdravie človeka. Ohrozené sú tiež medziludské vztahy, ktoré tvoria základ spoločnosti. S rozvojom moderných technológií je spojené aj širenie tzv. reprodukčných práv, ktoré sú propagované na národnej i medzinárodnej úrovni.

Zretelne a jednoznačne povedané, cesty $\mathrm{k}$ splodeniu dietata, ktoré nie sú $\mathrm{v}$ súlade s úmyslom Stvoritela a Darcu života, nemôže Cirkev považovat za morálne ospravedlnitelné. Ak teda muž alebo žena nie sú spôsobilí $\mathrm{k}$ splodeniu dietata a terapeutické alebo chirurgické metódy liečby neplodnosti nie sú účinné, majú prijat bezdetnost ako svoju špecifickú životnú výzvu. Cirkev v takýchto prípadoch odporúča adopciu, osvojenie si dietata, samozrejme, po vzájomnom súhlase obidvoch manželov. K prípustným prostriedkom, avšak iba v rámci cirkevnej ikonómie, môže byt za určitých špecifických duchovných okolností zarátané umelé oplodnenie medzi manželmi (takýto názor zdiela napríklad Ruská pravoslávna cirkev $)^{21}$.

Čo však je neprípustné, je manipulácia spojená s darcovstvom spermií, ktorá narúša plnost' osobnosti a výlučnost' manželských vztahov. Neprirodzené a eticky neprípustné je tiež tzv. zástupné materstvo (donosenie oplodneného vajička „tretou stranou“ a jeho „vrátenie“), a rovnako tak rôzne druhy mimotelového oplodnenia, ktoré manipulujú, pripravujú, konzervujú a dokonca ničia tzv. nadpočetné zárodky.

20 V. Holovačová, K problematike medzištátneho osvojenia, „Sociálna a Duchovná Revue" roč. II, č. 3, (2011), s. 35.

${ }^{21}$ Základy sociální koncepce Ruské pravoslavné církve, Červený Kostelec 2009, s. $100-101$. 


\section{Bibliografia}

\section{Pramene}

Biblia. Písmo Sväté Starej a Novej Zmluvy, Tranoscius a Slovenská biblická spoločnost', Liptovský Mikuláš a Banská Bystrica 1999.

Písmo Sväté. Nová Zmluva a Žalmy. Slovenský ekumenický preklad, Slovenská biblická spoločnost', Banská Bystrica 1995.

Základy sociální koncepce Ruské pravoslavné církve, Červený Kostelec 2009.

\section{Patristická literatúra}

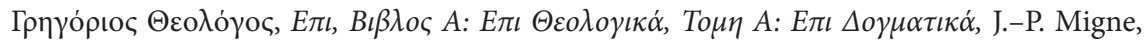
Patrologia Graeca 37, Paris 1862, s. 397521.

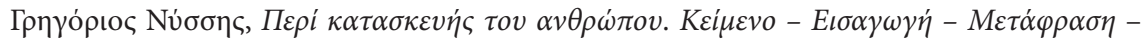

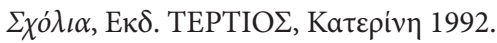

\section{Vedecká a odborná literatúra}

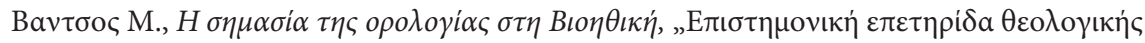

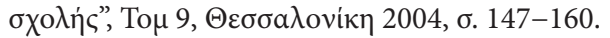

Holovačová V., K problematike medzištátneho osvojenia, „Sociálna a Duchovná Revue” roč. II, č. 3 (2011), s. 34-40.

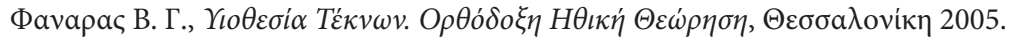

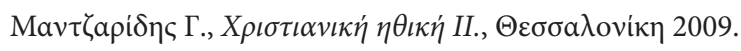

Nikolaos, metr., The Greek Orthodox position on the ethics of assisted reproduction, „Ethics, Bioscience and Life" Vol. 3, No. 3 (2008), p. 25-33.

Šipová M., Asistovaná reprodukcia v kontexte ludského práva na život, „Pravoslávny Biblický Zborník" zv. III (2014), s. 131-138.

Župina M., Význam terminológie v bioetike, „Pravoslávny Teologický Zborník“, zv. XXXIX nr 24 (2013), s. 60-70.

Župina M., Svätootcovská skúsenost' ako ukazovatel pravoslávnej teológie, Prešov 2013. 
A. Uniwersytet Papieski T.5. Jana Pawła II 